\title{
SUSTAINABLE SUPPLY CHAIN RELATIONSHIPS: ANALYSIS OF A PACKAGING MANUFACTURING CASE
}

\author{
Maria Rosaria Marcone ${ }^{1}$
}

DOI: https://doi.org/10.31410/ERAZ.2019.373

\begin{abstract}
Many firms attribute strategic importance to environmental issues. Among the firms that adopt this strategy, we can mention those that use the residues or waste of the processing cycles in further industrial transformation processes. The research work is focused on the study of an explanatory case of sustainability of the production process. As regards the methodology used, an excellent business case was analysed, and an interpretative, qualitative approach has been chosen. Although this is a research that is still in progress, some theoretical and conceptual systems can be proposed here.
\end{abstract}

Keywords: sustainability, supply chain integration, operations.

\section{INTRODUCTION}

They are inclined to make huge investments for the adoption of non-polluting technological solutions in production systems, as well as to start internal training activities to increase the skills of human resources in environmental matters and also to design specific and well detailed internal organizational procedures. This is the case of companies that use productive technologies powered by renewable energy sources and reduce the emission of $\mathrm{CO} 2$, or that use materials whose production does not compromise the production contexts of the countries of origin. Among the firms that adopt this strategy, we can mention those that use the residues or waste of the processing cycles in further industrial transformation processes. The research work is focused on the study of an explanatory case of sustainability of the production process. In practice, an excellent firm in the packaging industry has made huge productive investments to acquire and successfully implement a new production process aimed at reprocessing and regenerating the residues (processing waste) of the materials used in the main production process. One of the objectives of this study is to verify whether for a medium-sized business the external search produces more effective effects on innovative processes types.

Since recent researches suggest that process innovation and business model innovation (BMI) can be pursued separately or concurrently, the study intends to investigate what are the innovative processes relevant to a firm projected to sustainability. As far as the structure of the work is concerned, it is structured as follows: initially the theoretical framework that is still undergoing further systematization is presented, then the conduct of the investigative analysis in the field is illustrated, and finally some reader results that have been reached so far.

\section{THEORETICAL FRAMEWORK}

To innovate, organizations must search for new knowledge or for ways to recombine existing knowledge in novel ways, this is the pre-requisite to carry out research in new contexts in order to enter in distant industries. 
Firms are asked not to close themselves to their existing knowledge base or to the family one for the sector or sub-sector, but rather to undertake external search for knowledge. This is all the truer in the current era, where innovation is also recognized as a complex process that assembles different innovation types, such as product, process, and business model innovation (BMI).

Recent researches suggest that product, process, and BMI - a newly recognized innovation type [1], [2] can be pursued separately or concurrently [3], [4], [5].

Several authors have theoretically suggested separating BMI and process innovation, arguing that new business models can generate value through process innovation or without recourse to process innovation [6], [7]. Other authors consider BMI, product and process innovation as different innovation types [8], [5]. As well, other studies show that external search (relating to the number to the number of stakeholders with a different technological heritage and how intensively a firm resort to stakeholder innovation) is positively related to all the firm's innovative business processes types (business model, process) [3], [4].

The modification of the business model is concretely and profitably possible in the productive structures that with agility (operational agility) adapt to the new ways of competing.

The modification of the business model and the resulting value creation are sources of a competitive advantage that is also modified, since it is different, sometimes significantly, from the past. In strategic management studies, traditionally focused on the formulation of decisions, increasing importance is given to the analysis of how changes are generated and to the evaluation of the effects they generate [9].

The following two search traces are assumed.

H1a: The new production knowledge is the basis of the firm's innovative processes in a sustainability perspective.

H1b:Process innovation that leverages internal research is the prerequisite for diversifying the technological background and developing sustainable strategies in the historical and new business models.

A firm's ability to conceive performance-enhancing business models (BMs) in the sense of sustainability has become a cornerstone of competitive advantage. Sustainable supply chain governance is possible if it involves all the physical and information flows of the processes that make up the operations of the companies belonging to the supply chain.

Integration is important. The theoretical framework takes into consideration the relational approach [10], [11], [12] between economic actors based on two theoretical frameworks: the first, in the long term, takes into consideration the resource-based view; the second focuses on network analysis.

Numerous managerial studies have made use of the theoretical scheme focused on resources resource based view (RBV) - to analyse how various forms of integration between supply chain actors and companies impact on their performance [13], [14], [15]. The resource-based approach 
makes it possible to estimate the value of the 'relational resources' that are developed in the 'buyer-supplier' relations.

H2: The relationships between operations in the supply chain are the basis of the evolution of the value created by the supply chain.

\section{METHODOLOGY}

The methodology involves the longitudinal analysis of an excellent company case, located in central Italy, which has been investigated in the last five years. An interpretative, qualitative approach is chosen because it helps to navigate and understand the complex issues that are associated with the data quality concept, and its relation to the factors involving managerial practices to implement facilities in modern relationships within the supply chain [16]. 'Oriented case study' investigates the issue within a real-life context, drawing on the reviews of a number of sources, and provides the means to review theory and practice iteratively [17], [13], [18]. For a detailed analysis of the study and investigation methods, see the following table (table 1).

Table 1: Overview of data collection

\begin{tabular}{ll}
\hline Primary data & FIRM data \\
Semi-structured interviews \\
- entrepreneur \\
- manager of the first managerial line \\
- heads and foreman in the production area \\
- university curricular internship \\
- follow up interviews (with all the interviewees) \\
SUPPLIERS \\
- explorative interviews: managing director \\
- semi-structured interviews: managing director and workers of technical areas \\
- follow up interviews (with all the interviewees) \\
Internal communication documents \\
- economic-financial firm annual reports \\
- internal communication to employees \\
- internal workshops and seminars \\
External communication documents \\
- specialist presentations by managers for external audiences (on the occasion of the \\
Secondary data auditors' audit; supply chain partners) \\
- website and press releases downloaded (both of the firm and of the consortium) \\
- speeches on conferences and/or fairs \\
Publications relating to the firm by third parties \\
- Publications related to the consortium from business schools \\
- Master's degree thesis \\
\end{tabular}

\section{THE STRATEGY OF PRODUCTION DIVERSIFICATION FOR SUSTAINABILITY}

The business model is defined as new, when it is the result of the design, by managers and entrepreneurs, of a radically new activity system for objectives, structure and forms of governance (architectural novelty of the business) or of a system, in which activities with elements of novelty (objectives, structure, governance) are integrated with unmodified activities (complementary news of the business) [19], [20],[21]. 
Although the RBV places emphasis almost exclusively on the benefits deriving from collaborations based on the development of resources that are specific (unique or dedicated) to each relationship, and therefore difficult to imitate, interactions between diversified supply chains emerge with increasing force in the competitive scenario.

The analysis of the supply chain in the relational perspective considers the interdependence that is created between companies and the willingness that they have to initiate and control forms of interaction that increase the degree of integration of the supply chain. Following the research results obtained, it emerged that buyers and suppliers, developing relational skills, favour the profitable circulation of information, which is the basis of cooperation based on mutual trust. Such a strong degree of integration determines the reduction of conflicts and the formation of relational revenues. The integration of supply chain operators or supply chain integration (SCI) is made possible by the ability of companies to cooperate with 'critical suppliers and customers' and more cooperation involves business managers (intra-organizational collaboration), managers of different companies, but belonging to a group or to a multinational (co-operation between home-mother and subsidiary), and managers of completely autonomous companies (inter-organizational cooperation) (see table 2).

Firm utilizes relationships for competitive advantage by accessing, integrating, and leveraging external resources. Specifically, one would like to deepen the relationship perspective that is based or could even be better developed with the network-level design of network-type relational structures. Networks are structures that convey information in markets, provide a competitive advantage to some actors over others, and offer opportunities otherwise unavailable. The network analysis allows the scholar to grasp two theoretical frameworks using the main international managerial literature, namely the relational based view and the resource-based view. In agreement with the relational based view, the network perspective sees supply chain as business network, where business units or firms are represented by nodes, and long-term complex interactions between them are represented by links [22].

Table 2: Key features of the two types of innovation on which it primarily relies

\begin{tabular}{lll}
\hline Feature & Business Model Innovation & Process Innovation \\
\hline Unit of analysis & $\begin{array}{l}\text { Value chain system (as structured } \\
\text { between the focal firm, industrial clients, } \\
\text { suppliers, stakeholders) }\end{array}$ & $\begin{array}{l}\text { New technological process in internal } \\
\text { production system }\end{array}$ \\
\hline Knowledge needed & $\begin{array}{l}\text { Knowledge about new architectures of } \\
\text { productive combinations to reconfigure } \\
\text { production-based activity structure } \\
\text { needed and technical knowledge }\end{array}$ & $\begin{array}{l}\text { Technical tacit knowledge needed, often } \\
\text { difficult to codify }\end{array}$ \\
\hline $\begin{array}{l}\text { Relation within the value } \\
\text { chain }\end{array}$ & $\begin{array}{l}\text { Changes to the firm's value chain due } \\
\text { to changes in content, governance, and } \\
\text { structure of relationships with value chain } \\
\text { actors and with stakeholders }\end{array}$ & $\begin{array}{l}\text { Design of new production systems; design } \\
\text { new relationships in a value chain } \\
\text { (upstream/middle of the value chain) }\end{array}$ \\
\hline
\end{tabular}

\section{FINDINGS}

In the context of the resource-based view, academic interests are welcomed, stating that in the prerequisites of business, or strategic networks of success exploitation is much more recent. From a resource-based perspective firms differ in their capability to shape and exploit networks, to extent that their capability to leverage networks has been identified as distinctive. 
Following the results obtained from the analysis of the case studied, it can be seen that especially the external search is positively related to the medium sized firm's innovative business processes types.

If firms seek increased operational performance, market performance, innovation and financial performance, they need to develop network specific capabilities. One such critical capability refers to management skills and competencies in developing valid views of networks and their potential evolution, a condition to perceive the opportunities embedded in networks.

Recent empirical studies refine the conceptualization of network pictures by testing the dimensions of this concept and adopting a dynamic view, focused on the processes through which networks are understood and strategy enacted within them.

Drawing on network analysis and RBV we find that established firms predominantly rely on newly and diversified external sources such as new process technology, relations with new stakeholders and internal sources (productive knowledge embedded in production systems and in internal R\&D and engineering processes) when introducing new business models and when innovating processes.

To innovate, organizations must search for new knowledge or for ways to recombine existing knowledge in novel ways. This is all the truer in the current era, where innovation is also recognized as a complex process that assembles different innovation types, such as process and business model.

We provide two contributions to the literature. First, the much stronger empirical association between external search and BMI than between external search and process innovation suggests that BMI might enable established firms to escape the prior knowledge corridor and broaden their horizons. Second, we theoretically compare and empirically confirm how search practices relate to different innovation types, arguing that the underlying knowledge required for different innovation types influences the appropriate search practice in non-large firms operating in manufacturing sectors with strong environmental problems.

\section{REFERENCES}

[1] Crossan, M.M., Apaydin, M. (2010). A multi-dimensional framework of organizational innovation: a systematic review of the literature, Journal of Management Studies, 47(6), pp. 1154-1191.

[2] Foss, N.J., Saebi, T. (2018). Business models and business model innovation: between wicked and paradigmatic problems, Long Range Planning, 51(2), pp. 200-227.

[3] Terjesen, S., Patel, P.C. (2017). In search of process innovations: the role of search depth, search breadth, and the industry environment, Journal of Management, 4(5), pp. 14211446.

[4] Trantopoulos, K., von Krogh, G., Wallin, M.W., Woerter, M. (2017). External knowledge and information technology: implications for process innovation performance, Management Information Systems Quarterly, 41(1), pp. 287-300.

[5] Snihur Y., Wiklund J. (2019). Searching for innovation: Product, process, and business model innovations and search behavior in established firms, Long Range Planning, 52(3), pp. 305-325. 
[6] Markides, C.C. (2013). Business model innovation: what can the ambidexterity literature teach us?, Academy of Management Perspectives, 27(4), pp. 313-323.

[7] Brunswickera S., Schecter A. (2019). Coherence or flexibility? The paradox of change for developers' digital innovation trajectory on open platforms, Research Policy, 48(8), pp. $1-16$.

[8] Bucherer, E., Eisert, U., Gassmann, O. (2012). Towards systematic business model innovation: lessons from product innovation management, Creative Innovation Management 21(2), pp. 183-198.

[9] Hock M., Clauss T., Schulz E. (2015). The Impact of Organizational Culture on a Firm's Capability to innovate the Business Model, R\&D Management, 46(3), pp. 433-450.

[10] Parmigiani, A., Rivera-Santos, M. (2011). Clearing a path through the forest: A meta-review of inter-organizational relationships, Journal of Management, 37(4), pp. 1108-1136.

[11] Cao, Z., Lumineau, F. (2015). Revisiting the interplay between contractual and relational governance: A qualitative and meta-analytic investigation, Journal of Operations Management, 33-34 (January), pp. 15-42.

[12] Gölgeci, I., Murphy, W. H., Johnston, D. A. (2018). Power-based behaviors in supply chains and their effects on relational satisfaction: A fresh perspective and directions for research, European Management Journal, 36(3), pp. 278-287.

[13] Flynn B.B., Baofeng B., Zhao X. (2010). The Impact of supply Chain Integration on Performance: A Contingency and Configuration Approach, Journal of Operations Management, 28(1), pp. 58-71.

[14] Cao M., Zhang Q. (2011), Supply Chain collaboration: Impact on collaborative Advantage and Firm Performance, Journal of Operations Management, 29(3), pp. 163-180.

[15] Schoenherr T., Swink M. (2012). Revisiting the Arcs of Integration: Cross-validations and Extensions, Journal of Operations Management, 34(1-2), pp. 99-115.

[16] Yin, R. (2008). Applications of Case Study Research. CA: SAGE Publications, Thousand Oaks.

[17] Ellram, L. M. (1996). The use of the case study method in logistics research, Journal of Business Logistics, 17(2), pp. 93-138.

[18] Henneberg, S., Mouzas, S., Naudé, P. (2010). Sense-making and management in business networks: Some observations, considerations, and a research agenda, Industrial Marketing Management, 39(3), pp. 355-360.

[19] Spieth P., Schneckenberg D., Matzler K. (2016). Exploring the Linkage between Business Model \& Innovation and the Strategy on the Firm, R\&D Management, 46(3), pp. 403-413.

[20] Teece D.J. (2010). Business Model, Business Strategy and Innovation, Long Range Planning, 43(2-3), pp. 172-194.

[21] Zott C., Amit R. (2010). Business Model Design: An Activity System Perspective, Long Range Planning, 43(2-3), pp. 216-226.

[22] Håkansson, H., Ford, D. (2002). How should companies interact in business networks?, Journal of Business Research, 55(2), pp. 133-139. 